\title{
Conceptualising a multidimensional model of information communication and technology project complexity
}

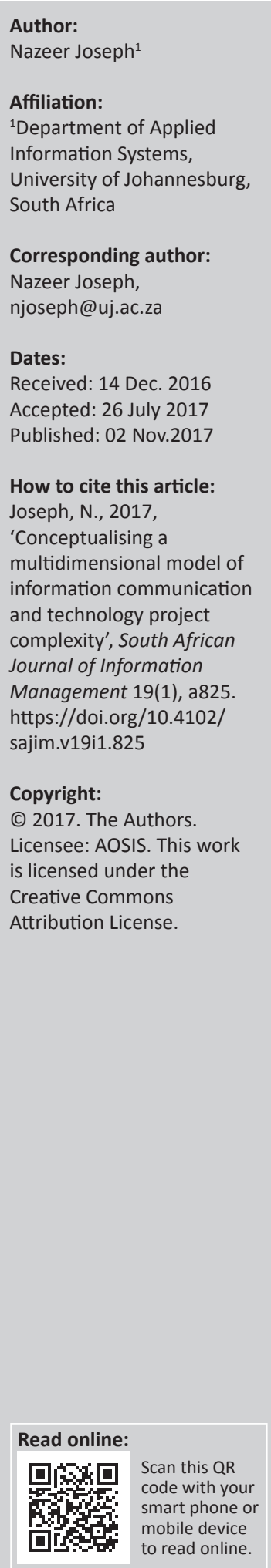

Background: Information communication and technology (ICT) projects are different from other projects, such as construction, and require a new perspective to determine their true nature. The lacklustre state of ICT projects has plagued researchers and practitioners for decades as they are yet to understand why ICT projects do not perform. Literature places significant emphasis on success criteria and success factors for determining project success, but this is a unilateral view as the level of complexity involved is underestimated. ICT projects, however, are multifaceted as there are a number of dimensions that influence the management and outcome of a project.

Objectives: This article aimed to illuminate how the dimensions are interdependent and interconnected through the construction of a conceptual model of ICT project complexity.

Methods: Content analysis was used to identify and understand the various dimensions and facilitated construction of the model.

Results: The article identified five dimensions that affect ICT projects, viz. project success, project lifecycle, project complexity, project types and project methods. Each dimension was analysed to understand the key constructs and elements that need to be considered. The dimensions were mapped in a multidimensional model.

Conclusion: The multidimensional model of ICT project complexity can be used by ICT project managers to more effectively manage projects as they are provided with a greater understanding of ICT project influences.

\section{Introduction}

Information communication and technology (ICT) projects require a new perspective to determine their true nature. This is particularly important considering that ICT projects are used to realise organisational strategies (Chari, Devaraj \& David 2007; Hu \& Quan 2005; Kim \& Sanders 2002). Organisations invest significant capital into ICT projects with the intention of catalysing improved organisation performance (Kalkan, Erdil \& Çetinkaya 2011; Kossaï \& Piget 2014). Literature asserts that there is a positive relationship between ICT investment and organisational performance (Farhanghi, Abbaspour \& Ghassemi 2013; Hu \& Quan 2005; Kalkan et al. 2011; Osei-Bryson \& Ko 2004;). ICT projects do, however, have a bad reputation of lacklustre performance rates both internationally and within South Africa (Curtis 2012; Joseph, Erasmus \& Marnewick 2014; Joseph \& Marnewick 2014; Hastie \&Wojewoda 2015; Marnewick2012). The constant struggle of understanding why ICT projects do not perform has plagued researchers and practitioners for decades.

Literature places significant emphasis on success criteria and success factors for determining project success, but this is a unilateral view as the level of complexity involved is underestimated (Bosch-Rekveldt et al. 2011; Cooke-Davies 2002; Dvir et al. 1998; Geraldi, Maylor \& Williams 2011; Hyväri 2006; Ika 2009; Vidal \& Marle 2008; Westerveld 2003). Similarly, ICT project research revolves around success criteria and success factors (Chow \& Cao 2008; Milis \& Mercken 2002; Purna Sudhakar 2012; Tan 1996). ICT projects, however, are multifaceted as there are a number of dimensions that influence the management and outcome of a project. Research is yet to identify and analyse the various dimensions of ICT projects to address their waning performance. Five dimensions were identified and analysed through content analysis, viz. project success, project lifecycle, project complexity, project types and project methods. Each dimension consists of multiple constructs and elements that need to be considered throughout an ICT project's lifespan. Moreover, understanding the intricacies of each dimension is essential to reimagine ICT project understanding. The notion is that a conceptual model of ICT project complexity can be constructed to illuminate how the dimensions are interdependent. 
The article is structured as follows. The first section details the research methodology used to construct the conceptual model. The second section analyses the five dimensions and discusses the various constructs and elements that constitute each dimension. The design and construction of the conceptual model are presented in the third section. The final section summarises and concludes with an outlook for future research.

\section{Research methodology}

A systematic literature review in the form of content analysis was used as it facilitates the analysis of textual material (Flick 2014:429; Martens \& Carvalho 2017; Pade, Mallinson \& Sewry 2008). Schreier (2014:170) asserts that qualitative content analysis is a method for systematically describing the meaning of qualitative data and [t]his is done by assigning successive parts of the material to the categories of a coding frame. The key concepts were first highlighted prior to grouping similar points and ideas (Flick 2014:436; He et al. 2015). Table 1 shows the search criteria used for conducting the content analysis and the initial results.

Schön, Thomaschewski and Escalona (2017) assert that a strict search protocol must be established when performing content analysis. This research first identified the key concepts to be investigated then precise keywords were defined to assist the content search process. The search space was limited to six databases which covered the identified project management concepts. Forward and backward snowballing was also employed when performing the content analysis. Forward snowballing searches literature which has cited the literature in question, while backward snowballing searches the reference list of literature (Badampudi, Wohlin \& Petersen 2015; Jalali \& Wohlin 2012; Schön et al. 2017). The final process was to conduct a manual scan of the literature sources to ensure adequate concept representation and enable conceptual model construction (Asher 2013; Dube \& Marnewick 2016; Schön et al. 2017).

\section{Conceptualising a multidimensional model of information communication and technology project complexity Project success}

Project success is a misnomer in literature as multiple definitions and interpretations exist. Project success was initially determined based on the triple constraint of time, cost and quality (Ika 2009; Jugdev \& Müller 2005; Todorović et al. 2015). However, it was realised that this perception was incomplete and stakeholder views had to be included, as well as benefits realisation (Baccarini 1999; Chih \& Zwikael 2015; Joseph \& Marnewick 2014; Lappe \& Spang 2014; Marnewick 2016; Serra \& Kunc 2015; Serrador \& Turner 2015; Wateridge 1998). The proliferation of project management led to the inception of various standards and methodologies such as $\mathrm{PMBOK}^{\circledR}$ Guide, P2M, APMBOK ${ }^{\circledR}$, PRINCE2 and ISO 21500. Table 2 indicates the varying perspectives regarding project success as each standard and methodology define the concept differently. The lack of consistency creates ambiguity around project success and distorts how it should be measured.

Researchers have embarked on expelling ambiguity around project success by empirically investigating what constitutes project success. Two distinct concepts encapsulate project success, viz. project management success and project product success (Baccarini 1999; Cooke-Davies 2002; De Wit 1988; Ika 2009; Jugdev et al. 2013; Van der Westhuizen \& Fitzgerald 2005).

TABLE 1: Content analysis search criteria.

\begin{tabular}{|c|c|c|c|}
\hline Concept & Keywords & Databases & Initial results \\
\hline Project success & $\begin{array}{l}\text { - Project success } \\
\text { - Project management success }\end{array}$ & $\begin{array}{l}\text { - ScienceDirect } \\
\text { - Emerald Insight } \\
\text { - SpringerLink } \\
\text { - Scopus } \\
\text { - Taylor \& Francis Online } \\
\text { - ACM Digital Library }\end{array}$ & $\begin{array}{l}\text { - Baccarini } 1999 \\
\text { - Bannerman } 2008 \\
\text { - Shenhar et al. } 2001\end{array}$ \\
\hline Project lifecycle & $\begin{array}{l}\text { - Project lifecycle } \\
\text { - Project management lifecycle } \\
\text { - Project process } \\
\text { - Project management process }\end{array}$ & $\begin{array}{l}\text { - ScienceDirect } \\
\text { - Emerald Insight } \\
\text { - SpringerLink } \\
\text { - Scopus } \\
\text { - Taylor \& Francis Online } \\
\text { - ACM Digital Library }\end{array}$ & $\begin{array}{l}\text { - Pinto \& Winch } 2016 \\
\text { - Varajão, Colomo-Palacios \& Silva } 2017 \\
\text { - Ward \& Chapman } 1995 \\
\text { - Wideman } 1989\end{array}$ \\
\hline Project complexity & $\begin{array}{l}\text { - Project complexity } \\
\text { - Project management complexity } \\
\text { - Complex project management }\end{array}$ & $\begin{array}{l}\text { - ScienceDirect } \\
\text { - Emerald Insight } \\
\text { - SpringerLink } \\
\text { - Scopus } \\
\text { - Taylor \& Francis Online } \\
\text { - ACM Digital Library }\end{array}$ & $\begin{array}{l}\text { - Baccarini } 1996 \\
\text { - Bakhshi, Ireland \& Gorod } 2016 \\
\text { - Bosch-Rekveldt et al. } 2011 \\
\text { - Dunović, Radujković \& Škreb } 2014 \\
\text { - Floricel, Michela \& Piperca } 2016 \\
\text { - Geraldi et al. } 2011 \\
\text { - Remington \& Pollack } 2007 \\
\text { - Senescu, Aranda-Mena \& Haymaker } 2013 \\
\text { - Vidal \& Marle } 2008 \\
\text { - Williams } 1999\end{array}$ \\
\hline Project types & $\begin{array}{l}\text { - Project types } \\
\text { - Project classification } \\
\text { - Types of project } \\
\text { - Classification of projects }\end{array}$ & $\begin{array}{l}\text { - ScienceDirect } \\
\text { - Emerald Insight } \\
\text { - SpringerLink } \\
\text { - Scopus } \\
\text { - Taylor \& Francis Online } \\
\text { - ACM Digital Library }\end{array}$ & $\begin{array}{l}\text { - Pinto \& Covin } 1989 \\
\text { - Shenhar } 2001 \\
\text { - Shenhar \& Dvir } 1996 \\
\text { - Shenhar et al. } 2016\end{array}$ \\
\hline Project methods & $\begin{array}{l}\text { - Project methods } \\
\text { - Project management methods } \\
\text { - software development methods } \\
\text { - Agile methods } \\
\text { - Devops } \\
\text { - Lean project management }\end{array}$ & $\begin{array}{l}\text { - ScienceDirect } \\
\text { - Emerald Insight } \\
\text { - SpringerLink } \\
\text { - Scopus } \\
\text { - Taylor \& Francis Online } \\
\text { - ACM Digital Library }\end{array}$ & $\begin{array}{l}\text { - Ballard \& Howell } 2003 \\
\text { - Dingsøyr et al. } 2012 \\
\text { - Fitzgerald \& Stol } 2017 \\
\text { - Misra, Kumar \& Kumar } 2009 \\
\text { - Reusch \& Reusch } 2013 \\
\text { - Van Waardenburg \& Van Vliet } 2013\end{array}$ \\
\hline
\end{tabular}


TABLE 2: Mapping of project success based on various project management standards and methodologies.

\begin{tabular}{|c|c|c|c|c|c|}
\hline Project success criteria & Ohara (2005) & $\begin{array}{l}\text { Office of Government } \\
\text { Commerce (2009) }\end{array}$ & $\begin{array}{l}\text { Association for Project } \\
\text { Management (2012) }\end{array}$ & $\begin{array}{l}\text { International Organization } \\
\text { for Standardization (2012) }\end{array}$ & $\begin{array}{l}\text { Project Management } \\
\text { Institute (2013) }\end{array}$ \\
\hline Quality & - & - & - & - & $x$ \\
\hline Timeliness & - & - & - & - & $x$ \\
\hline Budget compliance & - & - & - & - & $x$ \\
\hline Customer satisfaction & - & - & $x$ & $x$ & $x$ \\
\hline Objectives & - & $x$ & - & $x$ & - \\
\hline Achieve requirements & - & - & - & $x$ & - \\
\hline Manage risks & - & - & - & $x$ & - \\
\hline Support and commitment & - & - & - & $x$ & - \\
\hline Novelty & $x$ & - & - & - & - \\
\hline Differentiation & $x$ & - & - & - & - \\
\hline Innovation & $x$ & - & - & - & - \\
\hline
\end{tabular}

\section{Two-dimensional view of project success}

Project management success emphasises the project management process itself and how it was executed (Baccarini 1999). Project management success consists of 3 key criteria (Baccarini 1999; Camilleri 2011:18; CookeDavies 2002; Ika 2009; Pinkerton 2003:337):

- time, cost and quality

- quality of project management process

- stakeholder satisfaction regarding expectations during the project lifecycle.

Project product success places emphasis on the final output of a project and consists of 3 key criteria (Baccarini 1999; Camilleri 2011:18; Cooke-Davies 2002):

- realising project goal

- realising project purpose

- stakeholder satisfaction regarding the final project output.

While project management success may be differentiated from project product success, they are inseparable. Pinkerton (2003:344) asserts that [i]f the venture is not a success, neither is the project. Conversely, there is contention that the relationship between the two concepts is actually weak (Markus et al. 2000:344-345; Pinkerton 2003; Van der Westhuizen \& Fitzgerald 2005; Young \& Poon 2013). For example, there have been many cases (e.g. Sydney Opera House, Thames Barrier, Concorde) where projects were not delivered on time or within budget but were still deemed successful (Munns \& Bjeirmi 1996; Pinto \& Slevin 1988; Shenhar et al. 2005). Nevertheless, the contribution of project management success to project product success cannot be underestimated (Baccarini 1999; Ika 2009).

\section{Four-dimensional view of project success}

Shenhar et al. (2001) believed that the concept of project success was multidimensional in nature. The study revealed that project success constitutes four dimensions:

- Project efficiency: The constraints of time and cost are the focus of this dimension. There is a direct relationship between project success and project efficiency as the latter contributes considerably to the former (Serrador \& Turner 2015). Mir and Pinnington (2014) however, argue that more emphasis should be placed on the other dimensions as project efficiency is the least important.
- Impact on the customer: This dimension focuses on the importance of meeting customer requirements and needs (Shenhar 2001). Achieving customer satisfaction hinges on meeting their expectations and ensuring they use the final product (Joseph et al. 2014; Jugdev \& Müller 2005; Turner 1999; Wateridge 1998).

- Business success: Projects are a tool to realise organisational strategies and subsequently business success (Chih \& Zwikael 2015; Peterson 2002; Serra \& Kunc 2015). This agrees with the notion that project and organisational strategy should align as project performance has a significant impact on organisational performance (Aubry \& Hobbs 2011; Longman \& Mullins 2004; Mir \& Pinnington 2014).

- Preparing for the future: A successful project should facilitate future developments for the organisation such as creating new markets, creating new products and/or services, as well as development of new technology (Shenhar 2001). This dimension not only focuses on longterm organisational benefits but also on positioning the organisation to exploit future opportunities.

This article sought to provide a comprehensive interpretation of project success and thus includes an expanded fivedimensional view to provide more insight.

\section{Five-dimensional view of project success}

Bannerman (2008) developed a five-dimensional view to further solidify what constitutes project success. The five dimensions are:

- Process success: Emphasis is placed on the project management lifecycle specifically (Bannerman 2008). Various processes around a project are assessed including generic processes such as risk management and specific processes such as software quality certification for ICT projects (Chrissis et al. 2007).

- Project management success: This dimension is comparable to Baccarini (1999) and Shenhar et al. (2001). Time, cost and scope are used as measurement criteria.

- Product success: Meeting the needs of the various stakeholders is at the core of product success (Bannerman 2008). For example, Van der Westhuizen and Fitzgerald (2005) and Petter, Delone and Mclean (2013) contend that ICT project success is directly influenced by the output of the projects such as an information system. 
- Business success: Similar to the view of Shenhar et al. (2001), business success must be assessed to determine whether the project provided value and long-term benefits.

- Strategic success: Alignment between project and organisational strategy is paramount given that projects play a pivotal role in strategic success (Young \& Grant 2015). A project must be clearly defined initially as this facilitates the organisational strategy alignment (Turner 1999:82).

Figure 1 provides a comprehensive overview of the three views of project success. Each project success element is mapped showing the overarching relationship between each view. Project management success maps to project efficiency and impact on customer of the four-dimensional view and process success, project management success and product success of the five-dimensional model. Project product success maps to business success and preparing for the future elements of the four-dimensional model, as well as business success and strategic success of the five-dimensional model.

Project success was initially defined by two dimensions but later progressed to include more dimensions to address ambiguity around the concept. Figure 1 implies that project success is not simply articulated as a number of dimensions should be assessed to determine true project success.

\section{Project lifecycle}

The ultimate goal of project management is to deliver an output whether a product, service or both. A project's output is delivered via the execution of project management processes (Burke 2011:40-41; Project Management Institute 2013). The systematic structure of these processes constitutes the project lifecycle (Pinto \& Winch 2016; Ward \& Chapman 1995; Wideman 1989). Although literature is consistent regarding processes within a project lifecycle, the sources identified in Table 1 continuously direct to project management standards and methodologies and their perspectives regarding the project management process (Pinto \& Winch 2016; Varajão et al. 2017; Wideman 1989). This article followed this route and subsequently discusses the project lifecycle as defined in two of the most prolific standards and methodologies (Grau 2013; Hällgren et al. 2012; Starkweather \& Stevenson 2011; Svejvig \& Andersen 2015), viz. PMBOK ${ }^{\circledR}$ and PRINCE2.

\section{Project management standards and the project lifecycle}

The PMBOK ${ }^{\circledast}$ Guide modelled project management processes around five systematic processes (Project Management Institute 2013): (1) initiating, (2) planning, (3) executing, (4) monitoring and (5) controlling and closing. PMBOK ${ }^{\circledR}$ provides a generic approach to project management but does not detail specific process activities depending on project type. This does not bode well for ICT projects as they vary in terms of type, size and complexity. ICT projects require a more flexible and adaptive project management approach (Fernandes, Ward \& Araújo 2014; Malach-Pines, Dvir \& Sadeh 2009; Sheffield \& Lemétayer 2013; Söderlund 2011).

PRINCE2 was designed specifically for ICT projects (White 2014). Similar to PMBOK $^{\circledR}$, PRINCE2 provides various systematic processes and activities to be performed during a project's lifecycle (The Stationery Office 2010). PRINCE2 details seven key processes when performing a project (Office of Government Commerce 2009): (1) starting up a project, (2) directing a project, (3) initiating a project, (4) controlling a stage, (5) managing product delivery, (6) managing a stage boundary and (7) closing a project. An initial comparison of $\mathrm{PMBOK}^{\circledR}$ and PRINCE2 reveals that the processes differ marginally, and although there are more processes in PRINCE2, they can be directly mapped to the processes within PMBOK $^{\circledR}$. PRINCE2's systematic nature arguably implies that it also suffers from the same inflexibility as $\mathrm{PMBOK}^{\circledR}$ even though it was designed for ICT projects.

\begin{tabular}{|c|c|c|c|}
\hline \multicolumn{4}{|c|}{ Project Success } \\
\hline Two Dimensional Model & Four Dimensional Model & \multicolumn{2}{|c|}{ Five Dimensional Model } \\
\hline \multirow{2}{*}{$\begin{array}{l}\text { Project Management } \\
\text { Success }\end{array}$} & Project Efficiency & $\begin{array}{l}\text { Process } \\
\text { Success }\end{array}$ & $\begin{array}{c}\text { Project } \\
\text { Management } \\
\text { Success }\end{array}$ \\
\hline & Impact on the Customer & \multicolumn{2}{|c|}{ Product Success } \\
\hline \multirow[b]{2}{*}{ Project Product Success } & Business Success & \multicolumn{2}{|c|}{ Business Success } \\
\hline & Preparing for the Future & \multicolumn{2}{|c|}{ Strategic Success } \\
\hline
\end{tabular}

Source: Adapted from Baccarini, D., 1999, 'The logical framework method for defining project success', Project Management Journal 30, 25-32; Bannerman, P.L., 2008, 'Defining project success: A multilevel framework', in Proceedings of the Project Management Institute Research Conference, Warsaw, Poland, 13-16 July, pp. 1-14; Shenhar, A.J., Dvir, D., Levy, O. \& Maltz, A.C., 2001, 'Project success: A multidimensional strategic concept', Long Range Planning 34, 699-725. https://doi.org/10.1016/S0024-6301(01)00097-8

FIGURE 1: Mapping project success dimensions. 
The literature analysis revealed a limited view regarding ICT project's lifecycle and processes. The content analysis was subsequently expanded to include industry-related project management methodologies to further enlighten ICT project lifecycles and processes.

\section{Industry project management methodologies and the project lifecycle}

Major ICT organisations took it upon themselves to develop project management methodologies, from practice and experience, for ICT projects. The three most widely used methods are: Accelerated SAP (ASAP), Oracle Unified Method (OUM) and Microsoft Sure Step.

SAP designed ASAP to facilitate the implementation of various SAP solutions and modelled it around $\mathrm{PMBOK}^{\circledast}$ (Jain 2013; Musil \& Hoeliner 2009; SAP 2010). This methodology focuses on six processes (Jain 2013; Musil \& Hoeliner 2009; SAP 2010):

- Project preparation: Understanding project expectations and business needs, as well as initial planning, is the core of this process. Project preparation is analogous to the initiation and starting up process of $\mathrm{PMBOK}^{\circledR}$ and PRINCE2, respectively.

- Business blueprint: The main focus is on gathering business requirements and developing detailed documentation. This process is analogous to the planning process of $\mathrm{PMBOK}{ }^{\circledR}$ and initiating process of PRINCE2.

- Realisation: This process has two sub-processes, viz. baseline configuration and final configuration. Baseline configuration ensures primary scope requirements are met while final configuration deals with scope exceptions not previously dealt with. Realisation is analogous to executing and monitoring and controlling process of $\mathrm{PMBOK}^{\circledR}$, as well as controlling and managing product delivery of PRINCE2.

- Final preparation: Activities included in this process are technical testing, end-user training and system management and cutover activities. Final preparation is analogous to the monitoring and controlling process of $\mathrm{PMBOK}^{\circledR}$ and then closing a project process of PRINCE2.

- Go-live support: This process is analogous to the closing process of $\mathrm{PMBOK}{ }^{\oplus}$ and PRINCE2 as the main concern is to move the solution from a controlled project environment to operational environment.

- Operate: This process expands on the processes within $\mathrm{PMBOK}^{\circledR}$ and PRINCE2 as continuous support is emphasised. Focus is on refining lifecycle standards, processes and procedures while ensuring they align with the organisation's ICT and business strategy.

Similar to SAP, Oracle designed OUM to deploy Oracle solutions. OUM applies an iterative approach to managing ICT projects and is based on Unified Software Development Process (Oracle 2015). OUM revolves around five processes (Oracle 2015):

- Inception: Establishing project goals and objectives amongst the various stakeholders is the aim of this process. Inception is analogous to the initiating process of $\mathrm{PMBOK}^{\circledast}$, starting up process of PRINCE2 and project preparation process of ASAP.

- Elaboration: Initial scope and requirements are expanded during the elaboration process as more details are emphasised. These serve as the project benchmark. Elaboration is analogous to the planning process of $\mathrm{PMBOK}^{\circledast}$, initiating process of PRINCE2 and business blueprint process of ASAP.

- Construction: Developing and testing the solution are important during this process. Construction performs the same purpose as the executing and monitoring and controlling process of $\mathrm{PMBOK}^{\circledR}$, directing, controlling, managing product delivery and managing a stage boundary of PRINCE2 and realisation process of ASAP.

- Transition: During the transition process, the solution is either operationalised as a new system or replaces an older system. This process aligns to the monitoring and controlling as well as the closing process of $\mathrm{PMBOK}^{\circledR}$, directing, controlling, managing product delivery and managing a stage boundary of PRINCE2 and final preparation process of ASAP.

- Production: This process focuses on providing continuous support by monitoring the system and addressing any inherent issues not previously identified. Support, error and feature requests are continuously evaluated and prioritised for future release.

Microsoft Sure Step was designed to implement Microsoft Dynamics solutions (Microsoft 2013). The methodology includes both waterfall and iterative project management approaches. Sure Step includes six processes (Microsoft 2013; Shankar \& Bellefroid 2011):

- Diagnostic: Gap analysis is performed as this facilitates the development of a business case for the proposed solution. Diagnostic is analogous to the initiating process of $\mathrm{PMBOK}^{\oplus}$, starting up process of PRINCE2, project preparation process of ASAP and inception process of OUM.

- Analysis and design: The analysis process is considered the official start of the project while the design process focuses on formulating a complete solution design. Although these are two separate processes, they do overlap. Both processes include the following activities, viz. developing a detailed project plan, functional requirements, communication and training plans, quality and testing standards, change control plan, technical design, core team training, prototyping and data migration design. Both processes are analogous to the planning process of $\mathrm{PMBOK}^{\circledR}$, initiating process of PRINCE2, business blueprint of ASAP and elaboration process of OUM.

- Development: Building, configuring and testing the functions and data underpin the development process. This process is analogous to the executing and monitoring and controlling process of $\mathrm{PMBOK}^{\circledR}$, directing, controlling, managing product delivery and managing a stage boundary of PRINCE2, realisation process of ASAP and construction process of OUM. 
- Deployment: Focus is on transitioning to the new solution through user acceptance testing and training prior to final sign off. Deployment serves the same purpose as monitoring and controlling as well as closing process of $\mathrm{PMBOK}^{\circledR}$, directing, controlling, managing product delivery and managing a stage boundary of PRINCE2, final preparation process of ASAP and transition process of OUM.

- Operation: The final process performs the exact function as the operate process of ASAP and production process of OUM. The notion is to provide post-implementation support while addressing any inherent issues.

Traditional project management standards differ from industry project management methodologies as the latter include an operation or production process. This suggests that ICT projects should include a post-implementation process which focuses on ongoing support. ICT projects are considered more complex than other projects as there are multiple intangible elements which are difficult to assess. This influences the overall quality of ICT projects and could possibly be why they are often considered challenged or failures. The quality of an ICT project has a direct impact on expected organisational benefits (Gichoya 2005). It could, therefore, be argued that ICT projects should include an ongoing support process to address inherent issues.

\section{Mapping project management standards' and industry methodologies' processes}

Figure 2 maps the various project management processes and reveals that ICT projects should include the process of operating as they include a post-implementation process which focuses on ongoing support. The five standards and methodologies are arguably the same once mapped. Furthermore, although ASAP and OUM were created for ICT projects, they are still based on existing standards and methodologies such as $\mathrm{PMBOK}^{\circledR}$ and Unified Software
Development Process, respectively. This implies that all project management standards and methodologies apply the same principles and do not achieve the desired result of improved ICT project performance.

Projects are directly influenced by the increased level of complexity experienced today, especially ICT projects. The next section discusses the concept of project complexity and its inherent constructs.

\section{Project complexity}

Project complexity has been debated extensively in extant literature (Baccarini 1996; Cooke-Davies et al. 2007; Floricel et al. 2016; Geraldi \& Adlbrecht 2007; Geraldi et al. 2011; Vidal \& Marle 2008; Vidal, Marle \& Bocquet 2007; Williams 1999; Whitney \& Daniels 2013). Baccarini (1996:201) proclaims that complex projects demand an exceptional level of management, and that the application of conventional systems developed for ordinary projects have been found to be inappropriate for complex projects. This is further reiterated by Levin and Ward (2011:3) who argue that projects should be managed as complex systems to ensure they perform correctly. A consistent definition for project complexity is yet to emerge in literature regardless of the considerable research around the topic.

There are multiple views regarding what constitutes project complexity. Two decades of literature culminates in the identification of five project complexity constructs (Baccarini 1996; Bakhshi et al. 2016; Bosch-Rekveldt et al. 2011; Dunović et al. 2014; Floricel et al. 2016; Geraldi et al. 2011; Remington \& Pollack 2007; Senescu et al. 2013; Vidal \& Marle 2008; Williams 1999). The five constructs are shown in Table 3 . These constructs represent the most frequently used terms and categories to define project complexity. Comparable underlying elements and features were identified, understood and logically mapped where different terms and categories were used.

\begin{tabular}{|c|c|c|c|c|}
\hline РМВОК & PRINCE2 & ASAP & OUM & Sure Step \\
\hline Initiating & Starting up a project & Project preparation & Inception & Diagnostic \\
\hline Planning & Initiating a project & Business blueprint & Elaboration & $\begin{array}{l}\text { Analysis } \\
\text { Design }\end{array}$ \\
\hline Execution & \multirow{2}{*}{$\begin{array}{l}\text { Directing a project } \\
\text { Managing a stage boundary } \\
\text { Controlling a stage }\end{array}$} & \multirow{3}{*}{ Realisation } & \multirow{3}{*}{ Construction } & \multirow{3}{*}{ Developmen } \\
\hline Monitoring \& Controlling & & & & \\
\hline \multirow{2}{*}{ Closure } & \multirow{2}{*}{$\begin{array}{l}\text { Managing product delivery } \\
\text { Closing a project }\end{array}$} & & & \\
\hline & & $\begin{array}{l}\text { Final preparation } \\
\text { Go-live support }\end{array}$ & Transition & Deployment \\
\hline N/A & N/A & Operate & Production & Operation \\
\hline
\end{tabular}

Source: Adapted from Jain, A., 2013, Basic understanding on ASAP methodology for beginners, viewed 2 November 2015, from http://scn.sap.com/docs/DOC-48920; Musil, J. \& Hoeliner, R., 2009, The new ASAP methodology [Powerpoint Presentation], viewed 03 November 2015, from https://www.slideshare.net/brunon1/overview-of-asap-methodology-for-implementation-and-asapbusiness-add-ons; Oracle, 2015, Oracle Unified Method (OUM): Oracle's full lifecycle method for deploying Oracle-based business solutions, viewed 10 November 2015 , from http://www.oracle. com/us/products/consulting/resource-library/oracle-unified-method-069204.pdf; SAP, 2010, ASAP methodology roadmaps and phases, viewed 3 November 2015, from http://scn.sap.com/docs/ DOC-8032; Shankar, C. \& Bellefroid, V., 2011, Microsoft dynamics sure step 2010: The smart guide to the successful delivery of Microsoft dynamics business solutions, Packt Publishing, Birmingham, England; Microsoft, 2013, Sure step to customer through partner overview, Microsoft, Johannesburg, South Africa

FIGURE 2: Mapping the various project management processes. 
TABLE 3: Mapping project complexity constructs and literature sources.

\begin{tabular}{|c|c|c|c|c|c|}
\hline Literature source & Organisational complexity & Technical complexity & Environmental complexity & Uncertainty & Dynamics \\
\hline Baccarini (1996) & $x$ & $x$ & - & - & - \\
\hline Williams (1999) & $x$ & - & - & $x$ & - \\
\hline Remington and Pollack (2007) & $x$ & $x$ & $x$ & $x$ & $x$ \\
\hline Vidal and Marle (2008) & $x$ & $x$ & $x$ & - & - \\
\hline Bosch-Rekveldt et al. (2011) & $x$ & $x$ & $x$ & - & - \\
\hline Geraldi et al. (2011) & $x$ & $x$ & $x$ & $x$ & $x$ \\
\hline Dunović et al. (2014) & $x$ & - & $x$ & $x$ & - \\
\hline Bakhshi et al. (2016) & $x$ & $x$ & $x$ & $x$ & - \\
\hline Floricel et al. (2016) & $x$ & $\mathrm{x}$ & $x$ & - & - \\
\hline
\end{tabular}

\section{Organisational complexity}

Complexity surrounding the organisation itself is often underestimated (Baccarini 1996; Bosch-Rekveldt et al. 2011). A multitude of elements forms the foundation of organisational complexity:

- Vertical differentiation: This element assesses the number of levels in the organisational hierarchical structure, viz. structure depth (Baccarini 1996; Beyer \& Harrison 1979).

- Horizontal differentiation: Organisational units and task structure are observed within this element (Baccarini 1996). Firstly, organisational units relate to a number of formal units such as departments, groups and functional units (Baccarini 1996; Dunović et al. 2014). Secondly, task structure is broken down further into two divisions, viz. division of labour and personal specialisation (Baccarini 1996).

- Size: Many features are included in this element. Emphasis is placed on project duration, variety of project management methods and tools, capital expenditure, work hours, project team, site area and number of locations (Bakhshi et al. 2016; Bosch-Rekveldt et al. 2011; Geraldi et al. 2011; Xia \& Lee 2004; Padalkar \& Gopinath 2016; Vidal \& Marle 2008).

- Resources: Projects cannot be performed without organisational resources. This element pays attention to project drive (time, cost and quality), resource and skills availability, experience with involved parties, Health, safety, security and environment (HSSE) awareness, interfaces between different disciplines, number of financial resources and contract types (Bosch-Rekveldt et al. 2011; Brady \& Davies 2014; Floricel et al. 2016; Geraldi \& Adlbrecht 2007; Senescu et al. 2013; Vidal \& Marle 2008).

- Project team: A fundamental component of projects is the project team. Various considerations around the project team include the number of different nationalities, number of different languages, cooperation with jointventure partners and overlapping office hours (Baccarini 1996; Bakhshi et al. 2016; Geraldi \& Adlbrecht 2007; Maylor, Vidgen \& Carver 2008).

- Trust: Trust is a fundamental social construct required in project management that is based on trust in project team and trust in contractor (Bosch-Rekveldt et al. 2011; Geraldi et al. 2011; Killen \& Kjaer 2012; Maylor et al. 2008; Smyth, Gustafsson \& Ganskau 2010).
- Risk: Organisational risk influences project complexity, and risk management must be in place to mitigate risk (Bosch-Rekveldt et al. 2011; Floricel et al. 2016; Thamhain 2013).

- Interdependencies: Various interdependencies exist in organisational complexity, viz. environmental dependencies, resource sharing, schedule dependencies, interconnectivity and feedback loops in task and project networks, dependencies between actors, information system dependencies, objective dependencies, process interdependencies, stakeholder relations and team cooperation and communication (Brady \& Davies 2014; Baccarini 1996; Lu et al. 2015; Padalkar \& Gopinath 2016; Senescu et al. 2013; Tatikonda \& Rosenthal 2000; Vidal, Marle \& Bocquet 2011).

\section{Technical complexity}

Technical complexity was initially classified as technological complexity by Baccarini (1996). Extant literature has subsequently reclassified technological complexity as technical complexity after further investigation of project complexity constructs (Bosch-Rekveldt et al. 2011; Floricel et al. 2016; Remington \& Pollack 2007; Nguyen et al. 2015). This construct consists of:

- Differentiation: Projects follow processes which require various inputs and outputs during their lifecycle. This element specifically considers the number and diversity of inputs and/or outputs (Baccarini 1996; Brown 2008; Geraldi et al. 2011; Green 2004).

- Goals: Multiple goals are pursued when performing a project. This element takes an expanded view of goals and considers the number of goals, goal alignment and clarity of goals (Baccarini 1996; Bosch-Rekveldt et al. 2011; Floricel et al. 2016; Geraldi \& Adlbrecht 2007; Maylor et al. 2008; Tatikonda \& Rosenthal 2000; Vidal \& Marle 2008; Williams 1999).

- Scope: Various technical features influence the scope of a project, viz. scale of scope and quality requirements (Bosch-Rekveldt et al. 2011; Floricel et al. 2016; Geraldi \& Adlbrecht 2007; Vidal \& Marle 2008).

- Tasks: Project tasks can be more technical in nature as the number of tasks, variety of tasks and conflicting norms and standards influence project complexity (BoschRekveldt et al. 2011; Geraldi \& Adlbrecht 2007; Senescu et al. 2013; Vidal \& Marle 2008). 
- Experience: Project teams are particularly influenced by this element as experience is essential when performing projects. Newness of technology and experience with technology are two experience features which must be consider (Baccarini 1996; Bosch-Rekveldt et al. 2011; Dunović et al. 2014; Geraldi \& Adlbrecht 2007; Nguyen et al. 2015; Tatikonda 1999; Thomé et al. 2016; Vidal \& Marle 2008).

- Risk: Risks associated with technology is at the core of this element (De Bakker, Boonstra \& Wortmann 2010; Bosch-Rekveldt et al. 2011; Schwalbe 2013; Javani \& Rwelamila 2016; Tatikonda \& Rosenthal 2000).

\section{Environmental complexity}

Organisations operate in environments which can be considered more volatile in recent years (Heaslip 2015; Kappelman, Mckeeman \& Zhang 2007). Projects are subjected to these environments as they both directly and indirectly influence project complexity and outcomes (Cooke-Davies et al. 2007; Geraldi et al. 2011; He et al. 2015). Environmental complexity consists of the following elements:

- Stakeholders: There are a number of stakeholder features which influence project complexity, viz. number of stakeholders, variety of stakeholder perspectives, political influence, internal support and required local content (Baccarini 1996; Bosch-Rekveldt et al. 2011; Dunović et al. 2014; Geraldi \& Adlbrecht 2007; Geraldi et al. 2011; Remington \& Pollack 2007; Vidal \& Marle 2008; Williams 1999).

- Location: It is paramount to understand the location dynamic of a project and the following should be considered, viz. interference with existing site, weather conditions, remoteness of location and experience in country (Bosch-Rekveldt et al. 2011; El-Rayes \& Moselhi 2001; Floricel et al. 2016; Nguyen et al. 2015; Sohi et al. 2016; Yang, Huang \& Hsu 2014).

- Market conditions: Market conditions play internal and external influencing roles in projects. Specific attention should be paid to internal strategic pressure, stability of project environment and level of competition (BoschRekveldt et al. 2011; Dunović et al. 2014; Floricel et al. 2016; Geraldi \& Adlbrecht 2007; Geraldi et al. 2011; Maylor et al. 2008; Senescu et al. 2013).

- Risk: Environmental risks which are either manmade or natural must be considered within any project type (Bosch-Rekveldt et al. 2011; Dunović et al. 2014; Floricel et al. 2016; Remington \& Pollack 2007).

\section{Uncertainty}

The concept of uncertainty was originally observed in general management and subsequently propagated to project complexity (Geraldi et al. 2011; Williams 1999). Both the present and the future are captured by uncertainty as both the current and future states of each of the elements that make up the system being managed (Geraldi et al. 2011:976). Six underlying elements underpin uncertainty:
- Triple constraint: This element assesses uncertainty by focusing on the features of time, scope and cost (BoschRekveldt et al. 2011; Geraldi \& Adlbrecht 2007; Geraldi et al. 2011; Maylor et al. 2008; Remington \& Pollack 2007; Thomé et al. 2016).

- Activity: Regardless how well a project is planned, there is always a level of uncertainty regarding activities to be performed. Activity uncertainty focuses on uncertainty in methods as well as task uncertainty (Bosch-Rekveldt et al. 2011; Dunović et al. 2014; Geraldi \& Adlbrecht 2007; Geraldi et al. 2011; Maylor et al. 2008; Tatikonda \& Rosenthal 2000; Vidal \& Marle 2008; Williams 1999).

- Goals: This element focuses on one feature, viz. uncertainty of goals and objectives (Dunović et al. 2014; Geraldi et al. 2011; Lu et al. 2015; Maylor et al. 2008; Williams 1999).

- Technology: Technology changes and evolves at a rapid rate. Technological maturity and novelty are two key features which contribute to technology uncertainty within a project (Dunović et al. 2014; Geraldi \& Adlbrecht 2007; Geraldi et al. 2011; Maylor et al. 2008; Remington \& Pollack 2007; Tatikonda \& Rosenthal 2000).

- Stakeholders: Stakeholders uncertainty is driven by undisclosed participants and stakeholder competency (Geraldi 2008; Geraldi et al. 2011; Maylor et al. 2008).

- Information: Projects thrive on information and the more complete and accurate the information, the greater the chance of delivering the expected benefits (Geraldi et al. 2011; Maylor et al. 2008; Vidal et al. 2007). Incomplete information stifles project progress and project success (Babar, Ghazali \& Jawawi 2014; Dekkers \& Forselius 2007; Marnewick 2013).

\section{Dynamics}

The project complexity construct of dynamics encapsulates complexity around project change management (Geraldi et al. 2011; Maylor et al. 2008). Change management is inevitable during projects as goal and scope changes are particularly evident (Hwang \& Low 2012; Ibbs, Wong \& Kwak 2001;). Internal and external factors influence project change (Love et al. 2002). Internal factors include inter alia, poor budgeting, shortage of resources, lack of departmental integration and poor stakeholder engagement (Hwang \& Low 2012; Ibbs et al. 2001). External factors include inter alia, government interference, economical challenges, legal disputes and weather anomalies (Hwang \& Low 2012). These factors are arguably related to the elements and features discussed within environmental complexity. Change management is the core element of this construct with focus on the change process, number of changes, scope of changes, frequency of changes, impact of changes and change over time (Geraldi \& Adlbrecht 2007; Geraldi et al. 2011; Love et al. 2002; Muller, Geraldi \& Turner 2012; Remington \& Pollack 2007; Whyte et al. 2016).

Literature argues that technology is the key driving factor determining project type (Müller \& Turner 2007a, 2007b; Shenhar 2001; Shenhar \& Dvir 1996; Shenhar et al. 1997, 2001, 
2016). Project type, therefore, plays an influential role when managing ICT projects. Furthermore, this compounds the level of project complexity as it adds another management dimension.

\section{Project types}

The evolution of project management brought about the notion that all projects are the same. In reality, there are stark differences between projects. Pinto and Covin (1989) assert that

the prevailing tendency among the majority of academics has been to characterize all projects as fundamentally similar...the implicit view of many academics could be represented by the axiom 'a project is a project is a project. (p. 49)

Shenhar and Dvir (1996) subsequently developed a model which details four types of projects: (1) low tech, (2) medium tech, (3) high tech and (4) super high tech. These project types follow a sliding scale based on the level of technological uncertainty. Low tech projects have a low level of technological uncertainty while super high tech projects have a very high level of uncertainty. The four project types are characterised as follows:

- Low tech projects: These projects employ existing and familiar technologies which can be reused (Shenhar 2001; Shenhar \& Dvir 1996; Shenhar et al. 2016). Low tech projects exhibit very low technological uncertainty. For example, ICT infrastructure projects, such as local area network deployment, primarily use standardised networking equipment.

- Medium tech projects: Medium tech projects are similar to low tech projects as they use existing technology but adapt them accordingly (Shenhar 2001; Shenhar \& Dvir 1996; Shenhar et al. 2001). These projects also incorporate a restricted amount of new technology to facilitate competitive advantage. For example, customisation projects often aim to update existing systems and technologies to meet project needs, for example, upgrading a wired network to include wireless access points to allow wireless connectivity.

- High tech projects: High tech projects implement a number of new technologies for the first time (Shenhar 2001; Shenhar \& Dvir 1996; Shenhar et al. 2016). Greater uncertainty exists as the project manager and team have minimal experience using new technologies (Dvir, Sadeh \& Malach-Pines 2006; Tatikonda \& Rosenthal 2000). For example, enterprise resource planning projects are often implemented to replace current systems and employ a vast amount of new technologies which work in tandem to create a fully integrated organisational ICT system.

- Super high tech projects: Super high tech projects use untested technologies to achieve project goals (Shenhar 2001; Shenhar \& Dvir 1996; Shenhar et al. 2001). An extreme degree of uncertainty exists during these projects as emerging and/or non-existent technology is developed for the project. For example, Nvidia and Microsoft aim to reshape servers to incorporate deep learning and artificial intelligence as this would enable organisations to exploit data and automate functions for improved organisational performance (Freund 2016).

\section{Project methods}

ICT projects make use of various project management methods or approaches. Software development projects, in particular, have catalysed the development of new methods. This section aims to illuminate four prevalent methods adopted for ICT projects, viz. software development lifecycle (SDLC), agile, DevOps and Lean:

- SDLC primarily relied on the waterfall model as it provided a systematic procedure for developing software solutions. The waterfall model is implemented in a sequential manner, and each phase is completed before moving onto the next (Sommerville 2011:30-31). The phases include (Sommerville 2011:30-31; Tsui \& Karam 2011:76-77) requirements definition and agreement, system and software design, coding, testing and integration. Waterfall, however, does not accommodate for ongoing requirement changes which are inevitable. Furthermore, iterations can be costly and require significant rework which results in incomplete or omitted requirements.

- Agile methods were introduced to address weaknesses of waterfall. Extreme programming (XP) and Scrum are the two most prevailing methods (Dingsøyr et al. 2012; Misra et al. 2009; Van Waardenburg \& Van Vliet 2013). XP and Scrum have different lifecycles but maintain the essence of iterative project development (Leffingwell 2010:14; Schwaber 2004:9). XP and Scrum may be considered independent methods but Sommerville (2011:72) asserts that they can be used together. This implies that other agile methods can be used together when deemed applicable.

- DevOps was developed to address the disjoint between development and deployment (De Bayser, Azevedo \& Cerqueira 2015; Fitzgerald \& Stol 2017; Virmani 2015). DevOps was created to meet the needs of large organisations which are developing large, complex ICT solutions (Fitzgerald \& Stol 2017). This method focuses on software and infrastructure development, deployment and integration (Cois, Yankel \& Connell 2014). DevOps centres around four principles (Fitzgerald \& Stol 2017): (1) culture, (2) automation, (3) measurement and (4) sharing.

- The philosophy of lean is embodied by five principles (Browaeys \& Fisser 2012; Putnik 2012; Wang, Conboy \& Cawley 2012; Womack \& Jones 2013): (1) value, (2) value stream, (3) flow, (4) pull and (5) perfection. Lean project management contrasts traditional project management not only in the goals it pursues, but also in the structure of its phases, the relationship between phases and the participants in each phase (Ballard \& Howell 2003:119). Reusch and Reusch (2013) assert that the following principles should be included alongside the above five principles for lean project management to exist: increase learning, make timely decisions, empower the project team and establish integrity, as well as have a holistic view. 


\section{Multidimensional model of information communication and technology project complexity}

The content analysis revealed that achieving project success is more difficult than initially perceived as there are many dimensions to ICT projects. A multidimensional view should be considered to illuminate and understand the complex nature of ICT projects. A multidimensional model of ICT project complexity is depicted in Figure 3.

The first dimension represents ICT project complexity and its inherent constructs. The second dimension addresses the four ICT project types while the third dimension focuses on the four project methods employed. The fourth dimension focuses on an ICT project's lifecycle and its processes. As argued above, ICT projects are naturally complex which should include a post-implementation process (operating) that focuses on ongoing support. The fifth and final dimension is the mapping of project success components to the preceding four dimensions.

As this is a conceptual model, a logical mapping approach was used to map the project success components. Table 2 shows the mapping of different views of project success. The components within the model were extracted from the two-dimensional view of project success as Baccarini (1999) explicitly detailed what each dimension constitutes. The components were subsequently mapped as follows:
- The time, cost and quality are mapped to the methods dimension as the project methods primarily dictate how the resources of time and cost are utilised. Furthermore, quality can also be determined by the method/s adopted. For example, significant focus is placed on delivering quality solutions when agile is adopted for ICT projects.

- Quality of project management process is mapped to the entire project lifecycle as quality is determined by the effectiveness of each process. The notion is that each process will perform as required if they are understood and implemented correctly.

- Stakeholder satisfaction relating to the project management process is mapped to initiation, planning, executing and monitoring and controlling. Similar to quality of project management process, stakeholders should be satisfied that these four processes were performed correctly to realise the project goal.

- Stakeholder satisfaction relating to the output of the project is mapped to the lifecycle processes of closing and operating. During these processes, stakeholders have a different view of success as more emphasis is placed on the final outcome of the project. Furthermore, stakeholders begin to evaluate whether the projects' output meets their goal and objectives as determined during the preceding processes of initiation and planning.

- Similarly, project purpose is mapped to the closing process as this process focuses specifically on whether stakeholders' requirements and expectations were met and benefits were realised. Project purpose is a short-term view of project success as immediate benefits and expectations are measured.

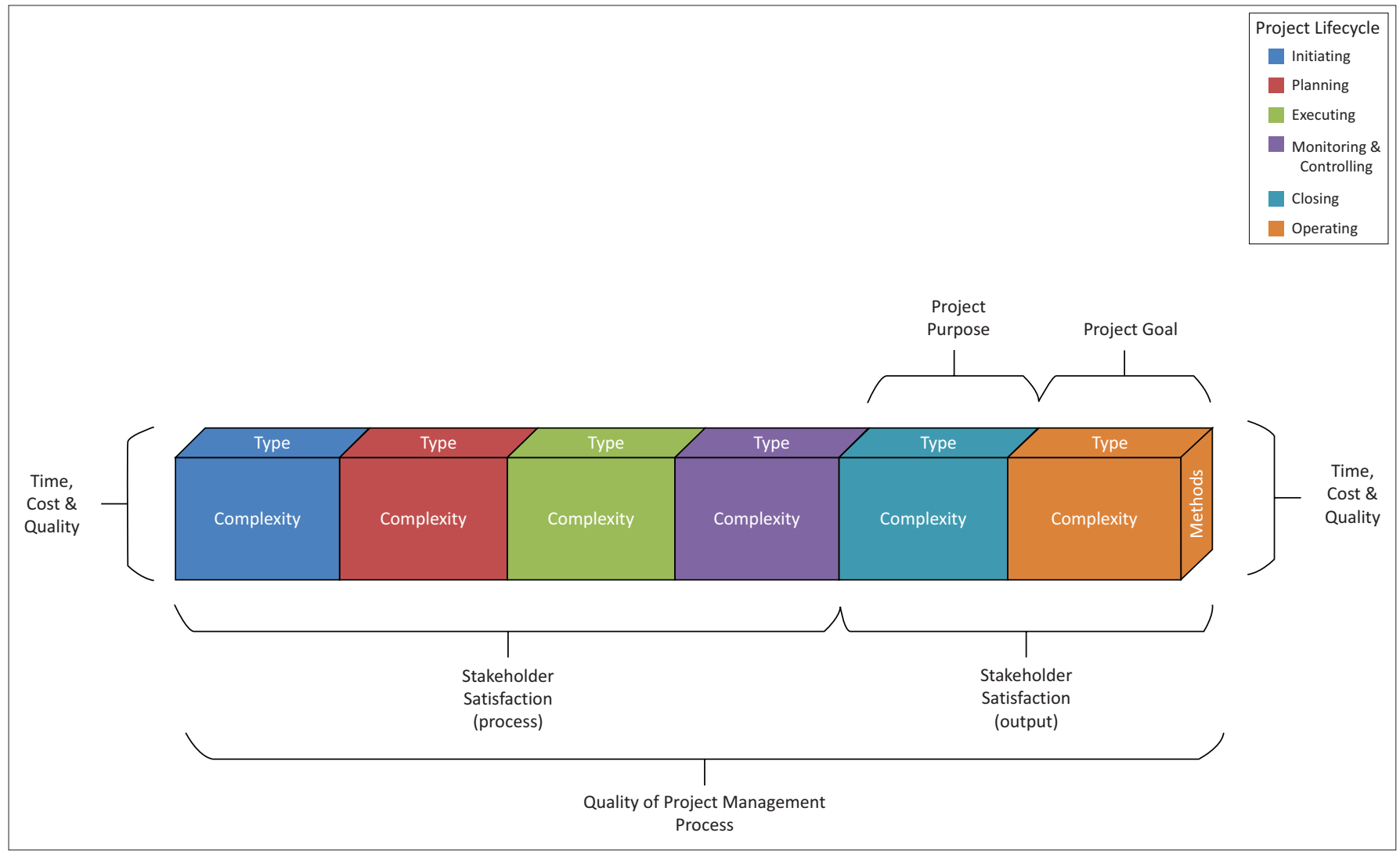

FIGURE 3: Multidimensional model of information communication and technology project complexity. 
- Project goal centres on meeting the strategic goals and objectives. This aligns to the operating process where refinement is pivotal to ensure alignment with the organisation's ICT and business strategy. Project goal, therefore, has a long-term view of project success as longterm benefits and expectations are measured.

\section{Conclusion}

ICT projects are infamous for their lacklustre performance and thus require a new perspective to understand the various complexities facing ICT projects. Achieving ICT project success is more difficult than initially perceived as there are many dimensions to consider. This article applies content analysis to illuminate and understand the various dimensions of ICT projects. Five concepts were investigated, viz. project success, project lifecycle, project complexity, project types and project methods. The article established that each concept constitutes a dimension effecting ICT projects. A multidimensional model of ICT project complexity was developed to illustrate how the dimensions are interdependent.

A number of contributions exist in this article. Firstly, the article identifies five dimensions which affect ICT projects. Secondly, each dimension is analysed to understand the key constructs and elements which need to be considered. Thirdly, the dimensions are mapped in a multidimensional model which can be used by practitioners to more effectively manage projects as they are provided with a greater understanding of ICT project influences. Finally, the conceptual model serves as the foundation for future research to reimagine ICT project management and move away from the unilateral view which is commonly depicted.

The research article does, however, have limitations. Firstly, the qualitative nature of content analysis has inherent issues around subjectivity as the dimensions, and constructs thereof, could be interpreted and understood differently by various individuals. In-depth conceptual mapping workshops with ICT project managers could be performed to gain a more comprehensive view of the dimensions and their constructs. Secondly, the content analysis cannot be considered exhaustive as not all academic databases were searched. It could be argued that there are other literature sources relevant to the search concepts which are yet to be discovered. Future research could consult other databases to validate, expand or contest this article's analysis. Finally, a drawback of a conceptual model is that it has not been empirically validated thus questioning its viability. Future research should test the model and update it accordingly to ensure real-world practicality.

ICT project management research has increased over the past years yet no practical improvement has been realised. This begs the question: Has ICT project management research stagnated or reached a limit? This stagnation can only be resolved by embarking on initiatives which boldly rethink and reimagine the concept of ICT project management.

\section{Acknowledgements Competing interests}

The authors declare that they have no financial or personal relationship(s) that may have inappropriately influenced them in writing this article.

\section{References}

Asher, H., 2013, Theory-building and data analysis in the social sciences, University of Tennessee Press, Knoxville, TN.

Association for Project Management, 2012, APM body of knowledge, Association for Project Management, Buckinghamshire, England.

Aubry, M. \& Hobbs, B., 2011, 'A fresh look at the contribution of project management to organizational performance', Project Management Journal 42, 3-16. https:// doi.org/10.1002/pmj.20213

Babar, M.I., Ghazali, M. \& Jawawi, D.N.A., 2014, 'Systematic reviews in requirements engineering: A systematic review', in 2014 8th Malaysian Software Engineering Conference (MySEC), September 23-24, pp. 43-48, Langkawi, Malaysia.

Baccarini, D., 1996, 'The concept of project complexity - A review', International Journal of Project Management 14, 201-204. https://doi.org/10.1016/02637863(95)00093-3

Baccarini, D., 1999, 'The logical framework method for defining project success', Project Management Journal 30, 25-32.

Badampudi, D., Wohlin, C. \& Petersen, K., 2015, 'Experiences from using snowballing and database searches in systematic literature studies', in Proceedings of the 19th International Conference on Evaluation and Assessment in Software Engineering, Nanjing, China, ACM, April 27-29, 2015, pp. 1-10.

Bakhshi, J., Ireland, V. \& Gorod, A., 2016, 'Clarifying the project complexity construct: Past, present and future', International Journal of Project Management 34 1199-1213. https://doi.org/10.1016/j.ijproman.2016.06.002

Ballard, G. \& Howell, G., 2003, 'Lean project management', Building Research \& Information 31, 119-133.

Bannerman, P.L., 2008, 'Defining project success: A multilevel framework', in Proceedings of the Project Management Institute Research Conference, Warsaw, Poland, 13-16 July, pp. 1-14.

Beyer, J.M. \& Harrison, M.T., 1979, 'A reexamination of the relations between size and various components of organizational complexity', Administrative Science Quarterly 24, 48-64. https://doi.org/10.2307/2989875

Bosch-Rekveldt, M., Jongkind, Y., Mooi, H., Bakker, H. \& Verbraeck, A., 2011, ‘Grasping project complexity in large engineering projects: The TOE (Technical, Organizational and Environmental) framework', International Journal of Project Management 29, 728-739. https://doi.org/10.1016/j.ijproman.2010.07.008

Brady, T. \& Davies, A., 2014, 'Managing structural and dynamic complexity: A tale of two projects', Project Management Journal 45, 21-38. https://doi.org/10.1002/ pmj.21434

Browaeys, M.J. \& Fisser, S., 2012, 'Lean and agile: An epistemological reflection', The Learning Organization 19, 207-218. https://doi.org/10.1108/09696471211219903

Brown, C.J., 2008, 'A comprehensive organisational model for the effective management of project management', South African Journal of Business Management 39, 1-10.

Burke, R., 2011, Advanced project management: Fusion method XYZ: A project methodology systems approach for the project sponsor to develop and implement corporate strategy, Burke Publishing, London, England.

Camilleri, E., 2011, Project success: Critical factors and behaviours, Gower, Farnham, England.

Chari, M.D.R., Devaraj, S. \& David, P., 2007, 'International diversification and firm performance: Role of information technology investments', Journal of World Business 42, 184-197. https://doi.org/10.1016/j.jwb.2007.02.004

Chih, Y.-Y. \& Zwikael, O., 2015, 'Project benefit management: A conceptual framework of target benefit formulation', International Journal of Project Management 33, 352-362. https://doi.org/10.1016/j.ijproman.2014.06.002

Chow, T. \& Cao, D.-B., 2008, 'A survey study of critical success factors in agile software projects', Journal of Systems and Software 81, 961-971. https://doi.org/10.1016/j. jss.2007.08.020

Chrissis, M. B., Konrad, M. \& Shrum, S., 2007, CMMI: Guidelines for process intergration and product improvement, Addison-Wesley, Boston, MA.

Cois, C.A., Yankel, J. \& Connell, A., 2014, 'Modern devops: Optimizing software development through effective system interactions', in IEEE International Professional Communication Conference (IPCC), October 13-15, Pittsburgh, PA pp. 1-7.

Cooke-Davies, T., 2002, 'The "real" success factors on projects', International Journa of Project Management 20, 185-190. https://doi.org/10.1016/S0263-7863(01) 00067-9

Cooke-Davies, T., Cicmil, S., Crawford, L. \& Richardson, K., 2007, 'We're not in Kansas anymore, toto: Mapping the strange landscape of complexity theory, and its relationship to project management', Project Management Journal 38, 50-61.

Curtis, J., 2012, The importance of a great project manager, viewed 11 March 2013, from http://quotient.net/blog/2012/6/25/the-importance-of-a-great-projectmanager/ 
De Bakker, K., Boonstra, A. \& Wortmann, H., 2010, 'Does risk management contribute to IT project success? A meta-analysis of empirical evidence', International Journal of Project Management 28, 493-503.

De Bayser, M., Azevedo, L.G. \& Cerqueira, R., 2015, 'ResearchOps: The case for DevOps in scientific applications', in IFIP/IEEE International Symposium on Integrated Network Management (IM), Ottawa, Canada, 11-15 May, pp. 1398-1404.

De Wit, A., 1988, 'Measurement of project success', International Journal of Project Management 6, 164-170. https://doi.org/10.1016/0263-7863(88)90043-9

Dekkers, C. \& Forselius, P., 2007, 'Increase ICT project success with concrete scope management', in Proceedings of the 8th International Conference on Product Focused Software Process Improvement, Springer-Verlag, Riga, Latvia, July 2-4 pp. 407-409.

Dingsøyr, T., Nerur, S., Balijepally, V. \& Moe, N.B., 2012, 'A decade of agile methodologies: Towards explaining agile software development', Journal of Systems and Software 85, 1213-1221. https://doi.org/10.1016/j.jss.2012.02.033

Dube, S. \& Marnewick, C., 2016, 'A conceptual model to improve performance in virtual teams', SA Journal of Information Management 18, 1-10. https://doi. org/10.4102/sajim.v18i1.674

Dunović, I.B., Radujković, M. \& Škreb, K.A., 2014, 'Towards a new model of complexity - The case of large infrastructure projects', Procedia - Social and Behavioral Sciences 119, 730-738. https://doi.org/10.1016/j.sbspro.2014.03.082

Dvir, D., Lipovetsky, S., Shenhar, A. \& Tishler, A., 1998, 'In search of project classification: A non-universal approach to project success factors', Research Policy 27, 915-935. https://doi.org/10.1016/S0048-7333(98)00085-7

Dvir, D., Sadeh, A. \& Malach-Pines, A., 2006, 'Projects and project managers: The relationship between project managers' personality, project types, and project success', Project Management Journal 37, 36-48.

El-Rayes, K. \& Moselhi, O., 2001, 'Impact of rainfall on the productivity of highway construction', Journal of Construction Engineering and Management 127 125-131. https://doi.org/10.1061/(ASCE)0733-9364(2001)127:2(125)

Farhanghi, A.A., Abbaspour, A. \& Ghassemi, R.A., 2013, 'The effect of information technology on organizational structure and firm performance: An analysis of
Consultant Engineers Firms (CEF) in Iran', Procedia - Social and Behavioral Consultant Engineers Firms (CEF) in Iran', Procedia - Social and
Sciences 81, 644-649. https://doi.org/10.1016/j.sbspro.2013.06.490

Fernandes, G., Ward, S. \& Araújo, M., 2014, 'Developing a framework for embedding useful project management improvement initiatives in organizations', Project Management Journal 45, 81-108. https://doi.org/10.1002/pmj.21441

Fitzgerald, B. \& Stol, K.-J., 2017, 'Continuous software engineering: A roadmap and agenda', Journal of Systems and Software 123, 176-189. https://doi.org/10.1016/j jss.2015.06.063

Flick, U., 2014, An introduction to qualitative research, Sage, London, England.

Floricel, S., Michela, J.L. \& Piperca, S., 2016, 'Complexity, uncertainty-reduction strategies, and project performance', International Journal of Project Managemen 34, 1360-1383. https://doi.org/10.1016/j.ijproman.2015.11.007

Freund, K., 2016, NVIDIA is not just accelerating Al, it aims to reshape computing viewed 19 November 2016, from http://www.forbes.com/sites/moorinsights/ 2016/11/17/nvidia-is-not-just-accelerating-ai-it-aims-to-reshape-computing/ \#21649bce2732

Geraldi, J., Maylor, H. \& Williams, T., 2011, 'Now, let's make it really complex (complicated): A systematic review of the complexities of projects', International Journal of Operations \& Production Management 31, 966-990. https://doi. org/10.1108/01443571111165848

Geraldi, J.G., 2008, 'Patterns of complexity: The thermometer of complexity', Project Perspectives XXIX, 4-9.

Geraldi, J.G. \& Adlbrecht, G., 2007, 'On faith, fact, and Interaction in projects', Project Management Journal 38, 32-43.

Gichoya, D., 2005, 'Factors affecting the successful implementation of ICT projects in government', Electronic Journal of e-Government 3, 175-184.

Grau, N., 2013, 'Standards and excellence in project management - In who do we trust?', Procedia - Social and Behavioral Sciences 74, 10-20. https://doi. org/10.1016/j.sbspro.2013.03.005

Green, G.C., 2004, 'The impact of cognitive complexity on project leadership performance', Information and Software Technology 46, 165-172. https://doi. org/10.1016/S0950-5849(03)00125-3

Hällgren, M., Nilsson, A., Blomquist, T. \& Söderholm, A., 2012, 'Relevance lost! A critical review of project management standardisation', International Journal of Managing

Hastie, S. \& Wojewoda, S., 2015, Standish Group 2015 Chaos report - Q\&A with Jennifer Lynch, viewed 6 January 2016, from http://www.infoq.com/articles/ standish-chaos-2015

He, Q., Luo, L., Hu, Y. \& Chan, A.P.C., 2015, 'Measuring the complexity of mega construction projects in China - A fuzzy analytic network process analysis',
International Journal of Project Management 33(3), 549-563. https://doi. org/10.1016/j.ijproman.2014.07.009

Heaslip, R.J., 2015, Managing organizational complexity: How to optimize the governance of programs and projects to improve decision making, Project Management Institute, Newtown, PA.

Hu, Q. \& Quan, J.J., 2005, 'Evaluating the impact of IT investments on productivity: A causal analysis at industry level', International Journal of Information Managemen 25, 39-53. https://doi.org/10.1016/j.jijinfomgt.2004.10.006

Hwang, B.-G. \& Low, L.K., 2012, 'Construction project change management in Singapore: Status, importance and impact', International Journal of Project Management 30, 817-826. https://doi.org/10.1016/j.ijproman.2011.11.001
Hyväri, I., 2006, 'Success of projects in different organizational conditions', Project Management Journal 37, 31-41.

Ibbs, C.W., Wong, C.K. \& Kwak, Y.H., 2001, 'Project change management system' Journal of Management in Engineering 17, 159-165. https://doi.org/10.1061/ (ASCE)0742-597X(2001)17:3(159)

Ika, L.A., 2009, 'Project success as a topic in project management journals', Project Management Journal 40, 6-19. https://doi.org/10.1002/pmj.20137

International Organization for Standardization, 2012, ISO 21500:2012 Guidance on project management, International Organization for Standardization, Geneva, Switzerland.

Jain, A., 2013, Basic understanding on ASAP methodology for beginners, viewed 2 November 2015, from http://scn.sap.com/docs/DOC-48920

Jalali, S. \& Wohlin, C., 2012, 'Systematic literature studies: Database searches vs. backward snowballing', in Proceedings of the ACM-IEEE International Symposium on Empirical Software Engineering and Measurement, ACM, Lund, Sweden, September 20-21, pp. 29-38.

Javani, B. \& Rwelamila, P.M.D., 2016, 'Risk management in IT projects - A case of the South African public sector', International Journal of Managing Projects in Business 9, 389-413. https://doi.org/10.1108/IJMPB-07-2015-0055

Joseph, N., Erasmus, W. \& Marnewick, C., 2014, 'The idle state of information and communication technology project management', Journal of African Business 15 , 184-196. https://doi.org/10.1080/15228916.2014.956641

Joseph, N. \& Marnewick, C., 2014, 'Structured equation modeling for determining ICT project success factors', in 2014 PMI Research and Education Conference, Project Management Institute, Portland, OR, July 27-29, pp. 1-30.

Jugdev, K. \& Müller, R., 2005, 'A retrospective look at our evolving understanding of project success', Project Management Journal 36, 19-31.

Jugdev, K., Perkins, D., Fortune, J. \& White, D., 2013, 'An exploratory study of project success with tools, software and methods', International Journal of Managing Projects in Business 6, 6-6. https://doi.org/10.1108/IJMPB-08-2012-0051

Kalkan, A., Erdil, O. \& Çetinkaya, Ö., 2011, 'The relationships between firm size, prospector strategy, architecture of information technology and firm performance', Procedia - Social and Behavioral Sciences 24, 854-869. https://doi. org/10.1016/j.sbspro.2011.09.114

Kappelman, L.A., Mckeeman, R. \& Zhang, L., 2007, 'Early warning signs of it project failure: The dominant dozen', Information Management Systems 23, 31-36. https://doi.org/10.1201/1078.10580530/46352.23.4.20060901/95110.4

Killen, C.P. \& Kjaer, C., 2012, 'Understanding project interdependencies: The role of visual representation, culture and process', International Journal of Project Management 30, 554-566. https://doi.org/10.1016/j.ijproman.2012.01.018

Kim, Y.J. \& Sanders, G.L., 2002, 'Strategic actions in information technology investment based on real option theory', Decision Support Systems 33, 1-11. https://doi. org/10.1016/S0167-9236(01)00134-8

Kossaï, M. \& Piget, P., 2014, 'Adoption of information and communication technology and firm profitability: Empirical evidence from Tunisian SMEs', The Journal of High Technology Management Research 25, 9-20. https://doi.org/10.1016/j.hitech. 2013.12.003

Lappe, M. \& Spang, K., 2014, 'Investments in project management are profitable: A case study-based analysis of the relationship between the costs and benefits of project management', International Journal of Project Management 32, 603-612. https://doi.org/10.1016/j.ijproman.2013.10.005

Leffingwell, D., 2010, Agile software requirements: Lean requirements practices for teams, programs, and the enterprise, Addison-Wesley, Boston, MA.

Levin, G. \& Ward, J.L., 2011, Program management complexity - A competency model, CRC Press, New York.

Longman, A. \& Mullins, J., 2004, 'Project management: Key tool for implementing strategy', Journal of Business Strategy 25, 54-60. https://doi.org/10.1108/0275 6660410558942

Love, P.E.D., Holt, G.D., Shen, L.Y., Li, H. \& Irani, Z., 2002, 'Using systems dynamics to better understand change and rework in construction project management systems', International Journal of Project Management 20, 425-436. https://doi. org/10.1016/S0263-7863(01)00039-4

Lu, Y., Luo, L., Wang, H., Le, Y. \& Shi, Q., 2015, 'Measurement model of project complexity for large-scale projects from task and organization perspective', International Journal of Project Management 33, 610-622. https://doi. org/10.1016/j.ijproman.2014.12.005

Malach-Pines, A., Dvir, D. \& Sadeh, A., 2009, 'Project manager-project (PM-P) fit and project success', International Journal of Operations \& Production Management 29, 268-291. https://doi.org/10.1108/01443570910938998

Markus, M.L., Axline, S., Petrie, D. \& Tanis, C., 2000, 'Learning from adopters' experiences with ERP: Problems encountered and success achieved', Journal of Information Technology 15, 245-265.

Marnewick, A., 2013, 'A socio-technical view of the requirements engineering process', D.Ing, University of Johannesburg.

Marnewick, C., 2012, 'A longitudinal analysis of ICT project success', in Proceedings of the South African Institute for Computer Scientists and Information Technologist Conference, ACM, Pretoria, South Africa, October 1-3, pp. 326-334.

Marnewick, C., 2016, 'Benefits of information system projects: The tale of two countries', International Journal of Project Management 34, 748-760. https://doi. org/10.1016/j.ijproman.2015.03.016

Martens, M.L. \& Carvalho, M.M., 2017, 'Key factors of sustainability in project management context: A survey exploring the project managers' perspective', International Journal of Project Management 35(6), 1084-1102. https://doi. org/10.1016/j.ijproman.2016.04.004 
Maylor, H., Vidgen, R. \& Carver, S., 2008, 'Managerial complexity in project-based operations: A grounded model and its implications for practice', Project Management Journal 39, S15-S26. https://doi.org/10.1002/pmj.20057

Microsoft, 2013, Sure step to customer through partner overview, Microsoft, Johannesburg, South Africa.

Milis, K. \& Mercken, R., 2002, 'Success factors regarding the implementation of ICT investment projects', International Journal of Production Economics 80, 105-117. https://doi.org/10.1016/S0925-5273(02)00246-3

Mir, F.A. \& Pinnington, A.H., 2014, 'Exploring the value of project management: Linking project management performance and project success', International Journal of Project Management 32, 202-217. https://doi.org/10.1016/j. ijproman.2013.05.012

Misra, S.C., Kumar, V. \& Kumar, U., 2009, 'Identifying some important success factors in adopting agile software development practices', Journal of Systems and Software 82, 1869-1890. https://doi.org/10.1016/j.jss.2009.05.052

Muller, R., Geraldi, J.G. \& Turner, J.R., 2012, 'Relationships between leadership and success in different types of project complexities', IEEE Transactions on Engineering Management 59, 77-90. https://doi.org/10.1109/TEM.2011. 2114350

Müller, R. \& Turner, J.R., 2007a, 'The influence of project managers on project success criteria and project success by type of project', European Management Journal 25, 298-309. https://doi.org/10.1016/j.emj.2007.06.003

Müller, R. \& Turner, J.R., 2007b, 'Matching the project manager's leadership style to project type', International Journal of Project Management 25, 21-32. https://doi. org/10.1016/j.ijproman.2006.04.003

Munns, A.K. \& Bjeirmi, B.F., 1996, 'The role of project management in achieving project success', International Journal of Project Management 14, 81-87. https:// doi.org/10.1016/0263-7863(95)00057-7

Musil, J. \& Hoeliner, R., 2009, The new ASAP methodology [Powerpoint Presentation], viewed 03 November 2015, from https://www.slideshare.net/brunon1/overviewof-asap-methodology-for-implementation-and-asap-business-add-ons Nguyen, A.T., Nguyen, L.D., Le-Hoai, L. \& Dang, C.N., 2015, 'Quantifying the complexity
of transportation projects using the fuzzy analytic hierarchy process', International Journal of Project Management 33, 1364-1376. https://doi.org/10.1016/j. ijproman.2015.02.007

Office of Government Commerce, 2009, Managing successful projects with PRINCE2 ${ }^{\text {TM }}$ Stationery Office, Norwich, England.

Ohara, S., 2005, A guidebook of project \& program management for enterprise innovation, Project Management Association of Japan, Tokyo, Japan.

Oracle, 2015, Oracle Unified Method (OUM): Oracle's full lifecycle method for deploying Oracle-based business solutions, viewed 10 November 2015, from http://www.oracle.com/us/products/consulting/resource-library/oracle-unifiedmethod-069204.pdf

Osei-Bryson, K.-M. \& Ko, M., 2004, 'Exploring the relationship between information technology investments and firm performance using regression splines analysis', Information \& Management 42, 1-13. https://doi.org/10.1016/j.im. 2003.09.002

Padalkar, M. \& Gopinath, S., 2016, 'Are complexity and uncertainty distinct concepts in project management? A taxonomical examination from literature', International Journal of Project Management 34, 688-700. https://doi.org/10.1016/j. ijproman.2016.02.009

Pade, C., Mallinson, B. \& Sewry, D., 2008, 'An elaboration of critical success factors for rural ICT project sustainability in developing countries: Exploring the DWESA case', Journal of Information Technology Case and Application Research 10 32-55. https://doi.org/10.1080/15228053.2008.10856146

Peterson, M., 2002, Why are we doing this project?, PricewaterhouseCoopers, New York.

Petter, S., Delone, W. \& Mclean, E.R., 2013, 'Information systems success: The quest for the independent variables', Journal of Management Information Systems 29, 7-62. https://doi.org/10.2753/MIS0742-1222290401

Pinkerton, W., 2003, Project management: Achieving project bottom-line success, McGraw-Hill Education, New York.

Pinto, J.K. \& Covin, J.G., 1989, 'Critical factors in project implementation: A comparison of construction and R\&D projects', Technovation 9, 49-62. https://doi.org/ 10.1016/0166-4972(89)90040-0

Pinto, J.K. \& Slevin, D.P., 1988, 'Project success: Definitions and measurement techniques', Project Management Journal 19, 67-72.

Pinto, J.K. \& Winch, G., 2016, 'The unsettling of "settled science:" The past and future of the management of projects', International Journal of Project Management 34 237-245. https://doi.org/10.1016/j.ijproman.2015.07.011

Project Management Institute, 2013, 'A guide to the project management body of knowledge: PMBOK ${ }^{\circ}$ Guide', 5th edn., Project Management Institute, Newtown Square, PA.

Purna Sudhakar, G., 2012, 'A model of critical success factors for software projects', Journal of Enterprise Information Management 25, 537-558. https://doi. org/10.1108/17410391211272829

Putnik, G.D., 2012, 'Lean vs agile from an organizational sustainability, complexity and learning perspective', The Learning Organization 19, 176-182. https://doi. org/10.1108/09696471211219859

Remington, K. \& Pollack, J., 2007, Tools for complex projects, Gower, Farnham, England.
Reusch, P.J.A. \& Reusch, P., 2013, 'How to develop lean project management?', in IEEE 7 th International Conference on Intelligent Data Acquisition and Advanced Computing Systems (IDAACS), September 12-14, Berlin, Germany, pp. 547-550.

SAP, 2010, ASAP methodology roadmaps and phases, viewed 3 November 2015, from http://scn.sap.com/docs/DOC-8032

Schön, E.-M., Thomaschewski, J. \& Escalona, M.J., 2017, 'Agile requirements engineering: A systematic literature review', Computer Standards \& Interfaces 49 79-91. https://doi.org/10.1016/j.csi.2016.08.011

Schreier, M., 2014, 'Qualitative content analysis', in U. Flick (ed.), The Sage handbook of qualitative data analysis, pp. 170-183, Sage, London, England.

Schwaber, K., 2004, Agile project management with scrum, Microsoft Press, Redmond, WA.

Schwalbe, K., 2013, Information technology project management, Cengage Learning, Stamford, CT.

Senescu, R.R., Aranda-Mena, G. \& Haymaker, J.R., 2013, 'Relationships between project complexity and communication', Journal of Management in Engineering 29, 183-197. https://doi.org/10.1061/(ASCE)ME.1943-5479.0000121

Serra, C.E.M. \& Kunc, M., 2015, 'Benefits realisation management and its influence on project success and on the execution of business strategies', International Journal of Project Management 33, 53-66. https://doi.org/10.1016/j.ijproman.2014. 03.011

Serrador, P. \& Turner, R., 2015, 'The relationship between project success and project efficiency', Project Management Journal 46, 30-39. https://doi.org/10.1002/ pmj.21468

Shankar, C. \& Bellefroid, V., 2011, Microsoft dynamics sure step 2010: The smart guide to the successful delivery of Microsoft dynamics business solutions, Packt Publishing, Birmingham, England.

Sheffield, J. \& Lemétayer, J., 2013, 'Factors associated with the software development agility of successful projects', International Journal of Project Management 31 459-472. https://doi.org/10.1016/j.ijproman.2012.09.011

Shenhar, A., Dvir, D., Guth, W., Lechler, T., Panatakul, P., Poli, M. et al., 2005, 'Project strategy: The missing link', in Proceedings of the Annual Meeting of the Academy of Management, August 5-10, pp. 1-19, Academy of Management, Honolulu.

Shenhar, A.J., 2001, 'One size does not fit all projects: Exploring classical contingency domains', Management Science 47, 394-414. https://doi.org/10.1287/mnsc.47.3. 394.9772

Shenhar, A.J. \& Dvir, D., 1996, 'Toward a typological theory of project management', Research Policy 25, 607-632. https://doi.org/10.1016/0048-7333(95)00877-2

Shenhar, A.J., Dvir, D., Levy, O. \& Maltz, A.C., 2001, 'Project success: A multidimensional strategic concept', Long Range Planning 34, 699-725. https://doi.org/10.1016/ S0024-6301(01)00097-8

Shenhar, A.J., Holzmann, V., Melamed, B. \& Zhao, Y., 2016, 'The challenge of innovation in highly complex projects: What can we learn from boeing's dreamliner experience?', Project Management Journal 47, 62-78. https://doi.org/10.1002/ pmj.21579

Shenhar, A.J., Levy, O. \& Dvir, D., 1997, 'Mapping the dimensions of project success', Project Management Journal 28, 5-13.

Smyth, H., Gustafsson, M. \& Ganskau, E., 2010, 'The value of trust in project business', International Journal of Project Management 28, 117-129. https://doi. org/10.1016/j.ijproman.2009.11.007

Söderlund, J., 2011, 'Pluralism in project management: Navigating the crossroads of specialization and fragmentation', International Journal of Management Reviews 13, 153-176. https://doi.org/10.1111/j.1468-2370.2010.00290.x

Sohi, A.J., Hertogh, M., Bosch-Rekveldt, M. \& Blom, R., 2016, 'Does lean \& agile project management help coping with project complexity?', Procedia - Social and Behavioral Sciences 226, 252-259. https://doi.org/10.1016/j.sbspro.2016.06.186

Sommerville, I., 2011, Software engineering, Pearson Education, Boston, MA.

Starkweather, J.A. \& Stevenson, D.H., 2011, 'PMP' certification as a core competency: Necessary but not sufficient', Project Management Journal 42, 31-41. https://doi. org/10.1002/pmj.20174

Svejvig, P. \& Andersen, P., 2015, 'Rethinking project management: A structured literature review with a critical look at the brave new world', International Journa of Project Management 33, 278-290. https://doi.org/10.1016/j.ijproman.2014. 06.004

Tan, R.R., 1996, 'Success criteria and success factors for external technology transfer projects', Project Management Journal 27, 45-56.

Tatikonda, M.V., 1999, 'An empirical study of platform and derivative product development projects', Journal of Product Innovation Management 16, 3-26. https://doi.org/10.1016/S0737-6782(98)00038-1

Tatikonda, M.V. \& Rosenthal, S.R., 2000, 'Technology novelty, project complexity, and product development project execution success: A deeper look at task uncertainty in product innovation', IEEE Transactions on Engineering Management 47, 74-87. https://doi.org/10.1109/17.820727

Thamhain, H., 2013, 'Managing risks in complex projects', Project Management Journal 44, 20-35. https://doi.org/10.1002/pmj.21325

The Stationery Office, 2010, Agile project and service management: Delivering IT services using ITIL, PRINCE2 and DSDM atern, The Stationery Office, London, England.

Thomé, A.M.T., Scavarda, L.F., Scavarda, A. \& Thomé, F.E.S.D.S., 2016, 'Similarities and contrasts of complexity, uncertainty, risks, and resilience in supply chains and temporary multi-organization projects', International Journal of Project Management 34, 1328-1346. https://doi.org/10.1016/j.ijproman.2015.10.012 
Todorović, M.L., Petrović, D.Č., Mihić, M.M., Obradović, V.L. \& Bushuyev, S.D., 2015 'Project success analysis framework: A knowledge-based approach in project
management', International Journal of Project Management 33, 772-783. https:// mai.org/10.1016/j.ijproman.2014.10.009

Tsui, F. \& Karam, O., 2011, Essentials of software engineering, Jones and Bartlett Publishers, Sudbury, MA.

Turner, J.R., 1999, The handbook of project-based management: Improving the processes for achieving strategic objectives, McGraw-Hill Book Co, Cambridge, England.

Van der Westhuizen, D. \& Fitzgerald, E.P., 2005, 'Defining and measuring project success', in D. Remenyi (ed.), European Conference on IS Management, Leadership and Governance 2005, pp. 157-163, Academic Conferences Limited, Reading, United Kingdom.

Van Waardenburg, G. \& Van Vliet, H., 2013, 'When agile meets the enterprise', Information and Software Technology 55, 2154-2171. https://doi.org/10.1016/j infsof.2013.07.012

Varajão, J., Colomo-Palacios, R. \& Silva, H., 2017, 'ISO 21500:2012 and PMBoK 5 processes in information systems project management', Computer Standards \& Interfaces 50, 216-222. https://doi.org/10.1016/j.csi.2016.09.007

Vidal, L.-A., Marle, F. \& Bocquet, J.-C., 2011, 'Using a delphi process and the analytic hierarchy process (AHP) to evaluate the complexity of projects', Expert System with Applications 38, 5388-5405. https://doi.org/10.1016/j.eswa.2010.10.016

Vidal, L.A. \& Marle, F., 2008, 'Understanding project complexity: Implications on project management', Kybernetes 37, 1094-1110. https://doi.org/10.1108/ 03684920810884928

Vidal, L.A., Marle, F. \& Bocquet, J.C., 2007, 'Modelling project complexity', in Proceedings of the International Conference on Engineering Design, August 28-31, pp. 1-10, Professional Engineering Publishing, Paris.

Virmani, M., 2015, 'Understanding DevOps \& bridging the gap from continuous integration to continuous delivery', in Fifth International Conference on Innovative Computing Technology (INTECH), May 20-22, Galicia, Spain, pp. 78-82. https:// doi.org/10.1109/INTECH.2015.7173368

Wang, X., Conboy, K. \& Cawley, O., 2012, “'Leagile” software development: An experience report analysis of the application of lean approaches in agile software development', Journal of Systems and Software 85, 1287-1299. https://doi. org/10.1016/j.jss.2012.01.061

Ward, S.C. \& Chapman, C.B., 1995, 'Risk-management perspective on the project lifecycle', International Journal of Project Management 13, 145-149. https://doi. org/10.1016/0263-7863(95)00008-E
Wateridge, J., 1998, 'How can IS/IT projects be measured for success?', International Journal of Project Management 16, 59-63. https://doi.org/10.1016/S02637863(97)00022-7

Westerveld, E., 2003, 'The project excellence model': Linking success criteria and critical success factors', International Journal of Project Management 21, 411418. https://doi.org/10.1016/S0263-7863(02)00112-6

White, K.R.J., 2014, 'Why IT matters: Project management for information technology', In P.C. Dinsmore \& J. Cabanis-Brewin (eds.), The AMA handbook of project management, pp. 479-490, AMACOM, New York.

Whitney, K.M. \& Daniels, C.B., 2013, 'The root cause of failure in complex IT projects: Complexity itself', Procedia Computer Science 20, 325-330. https://doi. org/10.1016/j.procs.2013.09.280

Whyte, J., Stasis, A. \& Lindkvist, C., 2016, 'Managing change in the delivery of complex projects: Configuration management, asset information and "big data", International Journal of Project Management 34, 339-351. https://doi.org/ 10.1016/j.ijproman.2015.02.006

Wideman, R.M., 1989, 'Successful project control and execution', Internationa Journal of Project Management 7, 109-113. https://doi.org/10.1016/0263 7863(89)90024-0

Williams, T.M., 1999, 'The need for new paradigms for complex projects', Internationa Journal of Project Management 17, 269-273. https://doi.org/10.1016/S02637863(98)00047-7

Womack, J.P. \& Jones, D.T., 2013, Lean thinking: Banish waste and create wealth in your corporation, Simon \& Schuster, New York.

Xia, W. \& Lee, G., 2004, 'Grasping the complexity of IS development projects', Communications of the ACM 47, 68-74. https://doi.org/10.1145/ 986213.986215

Yang, L.-R., Huang, C.-F. \& Hsu, T.-J., 2014, 'Knowledge leadership to improve project and organizational performance', International Journal of Project Management 32, 40-53. https://doi.org/10.1016/j.ijproman.2013.01.011

Young, R. \& Grant, J., 2015, 'Is strategy implemented by projects? Disturbing evidence in the state of NSW', International Journal of Project Management 33, 15-28. https://doi.org/10.1016/j.ijproman.2014.03.010

Young, R. \& Poon, S., 2013, 'Top management support - Almost always necessary and sometimes sufficient for success: Findings from a fuzzy set analysis', International Journal of Project Management 31(7), 943-957. https://doi.org/10.1016/j. ijproman.2012.11.013 